\title{
Sel ve İstanbul: Sel Riskine Karşı Yapılan Dere Islah Çalışmaları ile İlgili Bir Değerlendirme
}

\begin{abstract}
Alper Bodur ${ }^{1}$
Öz

Afetlerin kötü etkisinden korunmak amacıyla Türkiye'de birçok çalışma yapılmaktadır. Bu bakımdan, sel riski bulunan alanlarda yapılan dere ıslah çalışmaları önemli çalışmalardan biridir. Dere ıslahı çalışmaları, afet yönetiminin önemli bir ayağını oluşturan zarar azaltma çalışmaları kapsamında değerlendirildiğinde, sadece sel ve diğer tehlikelerin oluşmasını engellemez, ayrıca plansız yapılaşmanın ve çevre kirliliğinin önüne geçilmesini de sağlar. Bu çalışma ile, İSKI Genel Müdürlüğü tarafından Anadolu Yakası'nda yapılan dere ıslah çalışmaları ile ilgili durum değerlendirmesi yaparak karşılaşılan sorunları ortaya koymak, çalışmalarda gelinen aşamaları değerlendirmek ve birtakım öneriler getirmek amaçlanmaktadır. Araştırma kapsamında, çalışmalar esnasında karşılaşılan sorunlar irdelenmekte olup bu sorunların en önemlileri; mülkiyet, imar, yapılaşma, inşaat sırasında ortaya çıkan altyapı sorunlarıdır. Bütün bu sorunlara rağmen sel riskini ortadan kaldırmak için dere ıslah çalışmalarına devam edilmekte, fakat daha iyi bir koordinasyon ve yetki olması halinde dere ıslahlarının daha hızlı ve etkin bir şekilde tamamlanacağı öngörülmektedir. Araştırmada, sel riskini azaltmaya yönelik faaliyetlerin çok daha etkin bir şekilde tamamlanabilmesi için mevcut kanun ve yönetmeliklerin yeterli olmadığı, birtakım hukuki ve kurumsal düzenlemelere intiyaç olduğu kanısına ulaşılmıştır. Bütün bu olumsuzlukların giderilebilmesi için diğer kurum ve kuruluşları da içine alacak hukuki birtakım düzenlemeler yapılmalı, yetki karmaşasının önüne geçilmelidir. Ayrıca, kurum içi organizasyonun sel riskini en aza indirecek şekilde tekrar düzenlenmesi, acil durumlarda etkin müdahale amacıyla birtakım standart uygulama prosedürlerinin uygulamaya geçirilmesi gerektiği kanaatine ulaşıımıştır.
\end{abstract}

Anahtar Kelimeler: Afet, sel, dere ıslahı

\section{Flood and İstanbul: an Evaluation of the River Rehabilitation Studies Against Urban Floods}

\begin{abstract}
Many studies have been performed in Turkey in order to avoid the worst effects of the disasters. In this respect, the river rehabilitation studies carried out in any areas with flood risk are important ones. When assessed in the context of damage mitigation activities that constitute an important pillar of disaster management, river rehabilitation efforts not only prevent floods and other hazards from occurring but also prevent unplanned construction and environmental pollution. With this study, it is aimed to reveal the problems encountered by the situation assessment about the river improvement works carried out by the General Directorate of ISKI on the Anatolian side, to evaluate the progress in the works and to bring

\footnotetext{
${ }^{1}$ Mimarlık Fakültesi, Ondokuz Mayıs Üniversitesi, Samsun

*Ilgili yazar / Corresponding author: boduralper@yandex.com

Gönderim Tarihi: 09.04.2018

Kabul Tarihi: 26.04.2018
} 
some suggestions. Despite all the problems, river rehabilitation studies are being continued to remove the flood risk. However, in the case of better coordination and competence, it is envisaged that river rehabilitation will be completed more quickly and effectively. As a result of the research, it has been reached that there is a need for some legal and institutional arrangements, in which the existing laws and regulations are not sufficient for the activities to reduce flood risk to be completed more efficiently. To overcome all these negativities, legal arrangements should be made to cover other institutions and organizations and the confusion of authority should be avoided. It has also been found that the in-house organization should be redesigned to reduce the risk of flood and to implement some standard implementation procedures for effective intervention in emergencies.

Keywords: Disaster, flood, stream rehabilitation

\section{GíRiş}

İnsanoğlunu tarih boyunca etkileyen doğal afetlerden birisi de su/sel baskınlarıdır (Gönüllü, 2010). Sel ve taşkın olayları hem Türkiye'de hem de dünya üzerinde sık yaşanan, insan ölümlerine ve ciddi ekonomik kayıplara yol açan doğal afetlerin en önemlileri arasında yer almaktadır (Zeybek,1998; Ergünay, 2007). İnsanlar suya yakın olma, tarımsal amaçla kullanma, düz bir alana sahip olma gibi nedenlerle dere ve taşkın yataklarına yerleşmişlerdir (Korkanç, 2005). Maalesef şehirleşme, ulaşım, tarım ve sanayi alanlarının tespiti konularında çevreci olmayan tutum ve davranışların artması, sağnak yağışların büyük bir kısmının afete dönüşmesine neden olmaktadır (Sönmez ve Kesici, 2012).

Sel, dünyanın çeşitli yerlerinde ve Türkiye'de oldukça sık görülen, afete dönüşmesi durumunda önemli ölçüde can ve mal kaybına neden olan, kısmen ya da tamamen doğal etkenlerin neden olduğu bir doğal tehlikedir (Turgu ve Ceylan, 2008). Sel, suyun doğal ya da yapay yatağından taşarak çevre, yerleşim yerleri ve tarım alanlarında tehlikeye neden olması olarak tanımlanabilir (Kömüşçü vd, 2011).

Taşkınların en büyük nedenlerinden biri de şehir içerisinde veya çevresinde bulunan derelerin ıslah edilememesi ya da ıslah edilmesi adı altında kanal içerisine alınması ve akış kesitinin daraltılmasıdır (Karakuyu, 2002). Bu bakımdan normal bir doğa olayı olarak meydana gelen sel, yanlış arazi kullanımı, çarpık yerleşme, ormanların tahribi gibi beşeri nedenlerle doğanın dengesinin bozulması sonucu afete dönüşerek büyük sosyoekonomik sorunlara yol açmaktadır (Şahin ve Sipahioğlu, 2002, Akt: Özcan, 2006).

Türkiye atmosfer kökenli doğal afetlerin çok sık ve yaygın olarak görüldüğü bir orta kuşak ülkesidir. Ayrıca 3 tarafı bir nem kaynağı olan denizlerle, kıyıya paralel ve dik olarak uzanan dağlarla çevrilidir (Şahin ve Sipahioğlu, 2002; Akt: Ceylan vd., 2015).

Ülkemizde sel ya da taşkınlar, depremden sonra en büyük ekonomik kayıplara yol açan afetlerdir (Korkanç, 2005). Türkiye'de yıllar itibariyle meydana gelen taşkınlar incelendiğinde 1975-2015 döneminde yaşanan 1.209 adet taşkın neticesinde 720 vatandaşımız hayatını kaybetmiş, 893.933 ha alan zarar görmüştür (Url-1). DSi verilerine göre 1975-2012 yılları arasında 889 adet taşkın olayı meydana gelmiş, bu taşkınlar sonucunda 685 can kaybı yaşanırken, 862.854 hektar tarım arazisi taşkına maruz kalmış, 150 milyon TL. zarar meydana gelmiştir (Kadıoğlu, 2012, Akt: Dölek, 2015). Sepetçioğlu (2013), Türkiye'de görülen taşkınların aylara göre dağılımına bakıldığında, en fazla taşkın görülen ayın Haziran ayı olduğu, onu takip eden ayların ise Mayıs, Nisan ve Temmuz ayları olduğunu belirtmiştir (Sepetçioğlu, 2013). Taşkın sayısı itibariyle en yoğun iller Doğu Karadeniz, Akdeniz, Ege Bölgesinde yer almaktadır (Url-1). Bununla birlikte, büyük kentlerimizde, normal hava şartlarında dahi güçlükle yürütülen sosyo-ekonomik faaliyetler, kötü hava şartlarında, büyük 
ölçüde aksamaktadır. Bunun en büyük nedenlerinden biri, Türkiye'de meteorolojik karakterli doğal afetlere karşı erken uyarı ile mücadele edilemeyişidir (Kadıoğlu, 2008). Nüfusun ve kentsel alanın büyümesinin sağlıksız bir şekilde artması altyapıdan sorumlu kurumlar için büyük problemler yaratmıştır (Bahçeci, 2014). Sel baskınları, afet bölgesindeki yerel halk ile yerel yönetimleri sürekli meşgul etmiştir (Gönüllü, 2010). 2030 yılına gelindiğinde, kent sakinlerinin büyük çoğunluğu, yeterli altyapıya sahip olmayan, nüfusu bir milyon civarındaki şehir ve kasabalarda yaşıyor olacaktır (Ceylan vd., 2015).

Özetle, afetlerin kötü etkisinden korunmak amacıyla Türkiye'de birçok çalışma yapılmaktadır. Bu bakımdan, sel riski bulunan alanlarda yapılan dere ıslah çalışmaları önemli çalışmalardan biridir. Dere ıslahı çalışmaları, afet yönetiminin önemli bir ayağını oluşturan zarar azaltma çalışmaları kapsamında değerlendirildiğinde, sadece sel ve diğer tehlikelerin oluşmasını engellemez, ayrıca plansız yapılaşmanın ve çevre kirliliğinin önüne geçilmesini sağlar.

Bu çalışmada, yukarıdaki değerlendirmeler ışığında, taşkın ve su baskınlarının yaptığı hasarların önemine binaen İstanbul İli Anadolu Yakası sınırları içerisinde iSKi Genel Müdürlüğü'nün sel ve taşkın riski bulunan alanlarda yaptığı müdahaleler incelenerek yapılan çalışmalarda karşılaşılan zorluklar irdelenmekte ve yapılması gereken çalışmalarla ilgili öneriler getirilerek konu tartışmaya açılmaktadır. İstanbul'da dere ıslah çalışmaları ile ilgili yapılan çalışmalar ve alınan tedbirler mevcut kanun, yönetmelikler, v.d. çerçevesinde değerlendirilmektedir.

\section{Kurumsal Yapılanma Açısından Mevcut Durum}

Türkiye Cumhuriyeti Anayasası'nın "Devletin temel amaç ve görevleri” başlıklı 5 inci maddesinde; "...kişilerin ve toplumun refah, huzur ve mutluluğunu sağlamak; kişinin temel hak ve hürriyetlerini, sosyal hukuk devleti ve adalet ilkeleriyle bağdaşmayacak surette sınırlayan siyasal, ekonomik ve sosyal engelleri kaldırmaya, insanın maddi ve manevi varlığının gelişmesi için gerekli şartları hazırlamaya çalışmaktır..." hükmüne yer verilmiştir (TC Anayasa, 1982). Bu hüküm ile devlet, kişinin maddi ve manevi gelişmesi ile ilgili gerekli tüm şartları sağlamakla görevli olarak kişinin malı ve canı güvence altına alınmıştır.

Türkiye'de afetlerle ilgili farklı kurumlar için farklı görev tanımları yapan birçok kanun ve alt mevzuat bulunmaktadır. Bu kanunlar incelendiğinde sel ve taşkınlarla ilgili görev ve sorumlulukların tek bir mevzuatta toplanmadığı görülmektedir. Bu husus uygulamada zorluklara neden olmaktadır (Url-1).

Türkiye'de taşkınların öncesi, anı ve sonrası ile ilgili birçok kurum ve kuruluş bulunmakta olup ulusal düzeyde taşkın yönetiminden sorumlu kurum Orman ve Su İşleri Bakanlığı'dır. Bakanlık bu faaliyetlerini Su Yönetimi Genel Müdürlüğü, Devlet Su İşleri Genel Müdürlüğü, Meteoroloji Genel Müdürlüğü, Çölleşme ve Erozyonla Mücadele Genel Müdürlüğü, Orman Genel Müdürlüğü aracılığıyla sürdürmektedir. Ayrıca, Afet ve Acil Durum Yönetimi Başkanlığı (AFAD), Çevre ve Şehircilik Bakanlığı, Valilikler, İı Özel İdareleri, Büyükşehir Belediyeleri ile Belediyelerde sel ve taşkın konusunda yetkilidirler.

Afet ve Acil Durum Yönetimi Başkanlığı (AFAD), afetlerin önlenmesi ve zararlarının azaltılması, afetlere müdahale edilmesi ve sonrasındaki iyileştirme çalışmalarının süratle tamamlanması amacıyla gereken faaliyetlerin planlanması, yönlendirilmesi, koordine edilmesi ve etkin uygulanması için ülkenin tüm kurum ve kuruluşları arasında işbirliğini sağlamak üzere 2009 yılında dinamik yapıda teşkil edilmiş bir kurumdur îllerde afet ve acil durumlarla ilgili çalışmalar, AFAD koordinasyonunda, İl Afet ve Acil Durum Müdürlükleri (İ $A F A D)$ ve 11 ilde bulunan Sivil Savunma Arama ve Kurtarma Birlik Müdürlükleri vasıtasıyla yürütülmektedir (Url-3). 
5216 sayılı Büyükşehir Belediyesi Kanunu'nun 7/r maddesine göre ise "Su ve kanalizasyon hizmetlerini yürütmek, bunun için gerekli baraj ve diğer tesisleri kurmak, kurdurmak ve işletmek, derelerin ıslahını yapmak, kaynak suyu veya arıtma sonunda üretilen suları pazarlamak" Büyükşehir Belediyesi'nin görevleri ve yetkileri arasında sayılmıştır (Büyükşehir Belediyesi Kanunu, 2004).

İ düzeyinde taşkınla ilgili kurumlar valiye bağlı olarak çalışmaktadır. 20 Mayıs 2015 tarihli ve 29361 sayılı Resmi Gazetede yayınlanan Havza Yönetim Heyetlerinin Teşekkülü, Görevleri, Çalışma Usul ve Esaslarını belirleyen Tebliğin 8'inci maddesi uyarınca Valiliklerce II Su Yönetimi Koordinasyon Kurulları oluşturulmuştur.

II. Ormancılık ve Su Şurasında (2017) "meri mevzuat incelendiğinde; DSi ve Büyükşehir Belediyelerinin; dere yataklarında ıslah yaparak taşkınlara, derelerin yatak değiştirmesine ve özel mülkiyete ait olan veya olmayan tarıma elverişli taşınmazların kayba uğramasına önlem alması, belediyelerin; dere yataklarındaki yapılaşmalara izin vermemesi ve gereken önlemleri alması, Maliye Bakanlığının; derelerin yatak değişikliğinden kaynaklı arazisini kaybedenlerin kayıplarını yeniden oluşan arazilerden karşılayarak mevcut dere yataklarını özel mülkiyetten arındırması, Çevre ve Şehircilik Bakanlığının akarsulara ait kıyı kenar çizgilerini belirlemesi, Tapu ve Kadastro Genel Müdürlüğünün yaptığı kadastro ve yenileme kadastro uygulamalarında yasalarda belirlenen özel mülkiyete konu olmayacak alanlarla tescil işlemi gerçekleştirmemesi ve mahkemelerin tescile konu olmayacak alanlarda vatandaşlar tarafından açılan tescil davalarında gerekli özeni göstermesi gibi görevlerinin olduğu anlaşılmakta olup bu hususlar büyük önem arz etmektedir" denilmektedir (Orman ve Su İşleri Bakanlığı, 2017). Ancak afetlerin kötü etkilerine karşı hızlı bir şekilde müdahale, yeniden yapılanma ve normal yaşam koşullarına dönülmesi için çok daha entegre bir sisteme ihtiyaç duyulduğu ortadadır.

\section{Araştırma Alanı}

Genel olarak bakıldığında İstanbul gibi bir metropolün bitmek tükenmek bilmeyen bir altyapı sorunu vardır. Bugün bile İstanbul'un sayısız noktasında çok ciddi altyapı sorunları vardır. İstanbul'un en önemli sorunlarından birisi de ıslah edilememiş derelerdir. İstanbul'da günümüzde halen devam etmekte olan ve bir türlü önüne geçilemeyen çarpık kentleşme (Şekil 1) yerel yönetimlerin dere ıslahlarında yaşadıkları en önemli sorundur (Bingöl, 2006).

Dinç ve Bölen (2014), İstanbul derelerinin \%85'inin, doğal yapısını kirlilik, işgaller, yanlış arazi kullanım kararları nedeniyle kaybettiğini, derelerin koruma bantlarının kaçak yapılarla kaybolduğunu, her dere semt merkezlerine yaklaştıkça koruma bantlarının tamamına yakını yerleşim, sanayi gibi müdahalelerle kaçak ya da işgal edildiğini belirtmektedir (Dinç ve Bölen, 2014).

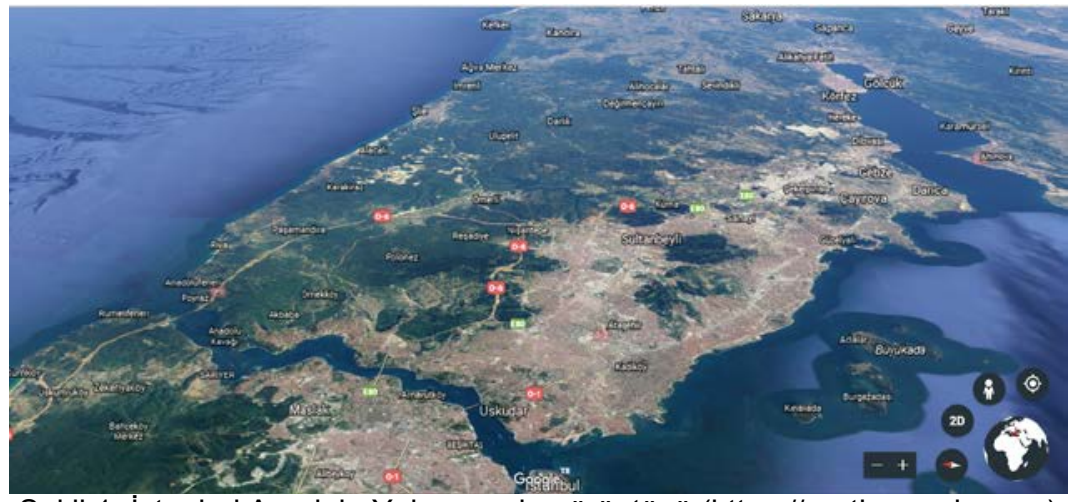

Şekil 1. İstanbul Anadolu Yakası uydu görüntüsü (https://earth.google.com) 
İstanbul İli, tek bir akarsu havzasından oluşmayıp, çok sayıda küçük akarsu havzasının birleşmesinden meydana gelmiştir. Marmara Denizi ve Karadeniz Havzaları'na ulaşan akarsular olmasının yanı sıra göllere, baraj göllerine ve İstanbul Boğazı'na ulaşan birçok dere bulunmaktadır (Garipağaoğlu, 2016). Havzalarda yer alan derelerin \%42'si Anadolu yakasında, \%58'i Avrupa Yakasında yer almaktadır (Dinç ve Bölen, 2014). İstanbul'da 1.855 km uzunluğunda dere bulunmaktadır. Derelerde sel baskınlarının önlenmesi için taşkın risk haritası çıkarılmakta ve öncelik sırasına göre ıslah çalışması yapılmaktadır. Ayrıca, derelerde periyodik temizlik ve bakım çalışması da yapılmaktadır (ISKi, 2016a).

26 Kasım 2013 tarihinde İstanbul Valiliği 3.Taşkın Koordinasyon Kurulu Toplantısı düzenlenmiştir. Toplantıda İSKİ adına da sunum yapılmış ve İBB'nin verdiği talimat ile Kasım 2012 yılında dere ıslah çalışmalarına başlandığı ifade edilmiştir (ISKİ, 2013a). Dere ıslahı uygulamalarında derelerin bazen her iki yanında, bazen bir tarafına kolektör inşa edilmek suretiyle atıksu ve yağmursuyu ayrıştııılarak derelere atıksu girişinin önlenmesi hedeflenmektedir.

ISKI 2016-2020 Stratejik Planı'nda belirtildiği gibi "Atık su kanal sistemini korumak, sel ve taşkınları önlemek ve yağmur sularından faydalanmak amacıyla yağmur sularının atık su kanal sisteminden tamamen ayrıştırılması" (ISKİ, 2013b) için sel baskınlarını önleyecek yaklaşık 750 km'lik dere ıslah projesi hazırlamak ve $10 \mathrm{~km}$ dere ıslahı inşaatını tamamlamak hedefi belirlenmiştir. 2015 yılının ilk altı ayı itibariyle 2011-2015 yılları arası 795 km dere ıslahı projesi üretilmiş ve 52 km dere ıslah edilmiştir (ISKI, 2015).

Dere ıslahının öncelikli hedefleri, mevcut dere kesitlerinin yetersiz kalması sebebiyle dere ıslahı yapılarak sel baskınlarını önlemek, karışık sistem çalışan derelerin atık su ve yağmur suyu kanal ayrımı ve atık su kolektörleri inşa edilerek, çevre kirliliği ve koku gibi olumsuzlukların giderilip bu derelerden göle ve denize atık su akışını engellemektir.

Ayrıca, taşkın sınırının belirlenmesine yönelik çalışmalarda yapılmaktadır. 2011-2015 yılları arasında taşkın sınırı belirlenen dere uzunluğu İstanbul genelinde $500 \mathrm{~km}$. dir. 71 farklı dere için, yüksek yağış koşulları altında modelleme yapılarak, taşkın risk haritaları hazırlanmıştır. Bu haritalar ile taşkın önlemli yapılaşma alanları ve bu alanlara ilişkin taşkın risk kotları íSKi tarafından verilen imar görüşlerinde ilgili belediyelere gönderilmektedir. 2016 yılında ihtiyaç duyulmaması sebebiyle taşkın sınırı belirleme çalışmasından vazgeçildiği belirtilmiş ve İstanbul geneli için yapılması planlanan \%17'lik oran gerçekleştirilmemiştir (ISKi, 2016b).

Anadolu Yakasında Tuzla, Kadıköy, Beykoz, Paşabahçe, Riva, Üsküdar, Küçüksu, Ömerli, Paşaköy, Reşadiye, Darlık, Ağva ve Şile Havzası olmak üzere 13 adet havza bulunmaktadır (Şekil 2). Her bir havzada bir veya daha fazla ana dere ve ana dereye bağlı yan kollar bulunmaktadır. 


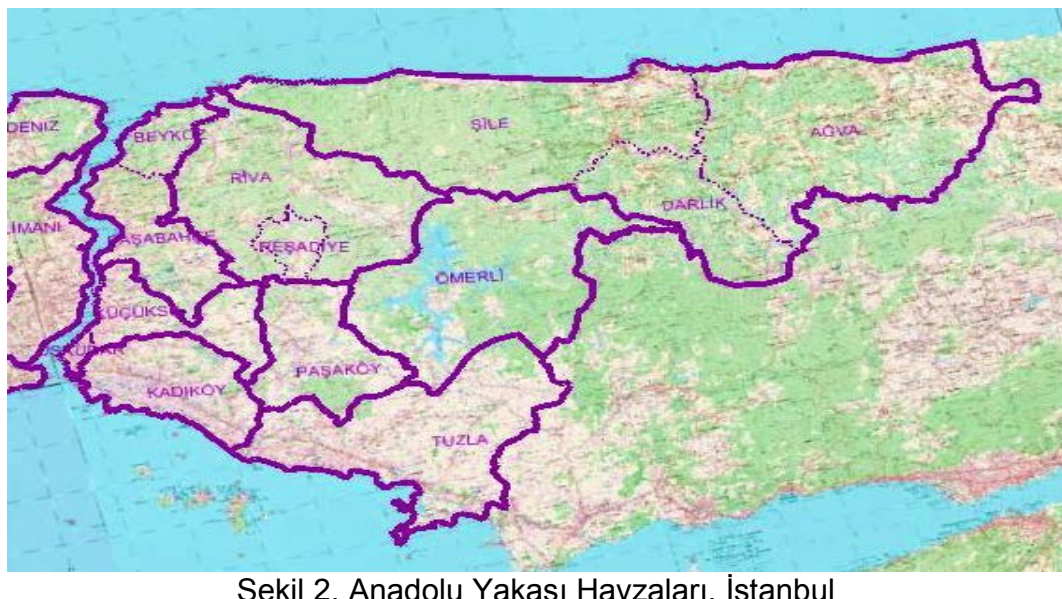

Tuzla ve Kadıköy havzalarında bulunan derelerin tamamı Marmara Denizi'ne dökülmektedir. Aşağıda, havzalardaki derelerin durumu 2017 yılı başı itibariyle incelenmektedir. Buna göre;

-Marmara Denizi'ne dökülen derelerin $143.041 \mathrm{~m}$ si ıslahlı, $30.647 \mathrm{~m}$ ıslahı gereken, 11.065 $\mathrm{m}$ ıslaha gerek olmayan ve $23.335 \mathrm{~m}$ si ise ıslahına devam edilen olmak üzere toplam $208.088 \mathrm{~m}$ dir.

-Beykoz, Paşabahçe, Üsküdar ve Küçüksu havzalarında bulunan derelerin tamamı Boğaziçi'ne dökülmektedir. Boğaziçi'ne dökülen derelerin $47.577 \mathrm{~m}$ si ıslahlı, $58.953 \mathrm{~m}$ ıslahı gereken, $27.825 \mathrm{~m}$ ıslaha gerek olmayan ve ıslahına devam edilen dere bulunmamak üzere toplam $134.355 \mathrm{~m}$ dir.

-Ömerli ve Paşaköy havzalarında bulunan derelerin tamamı Ömerli Barajı'na dökülmektedir. Ömerli Barajı'na dökülen derelerin 7.866 m si ıslahlı, 38.678 m ıslahı gereken, $39.292 \mathrm{~m}$ ıslaha gerek olmayan ve $22.424 \mathrm{~m}$ si ise ıslahına devam edilen olmak üzere toplam 108.260 $\mathrm{m}$ dir.

-Riva, Reşadiye, Ağva ve Şile havzalarında bulunan derelerin tamamı Karadeniz'e dökülmektedir. Karadeniz'e dökülen derelerin toplam uzunluğu $696.577 \mathrm{~m}$ dir. Darlık havzasında bulunan derelerin tamamı Darlık Barajı'na dökülmektedir. ISKI 2016 yılı verilerine göre havzada yaklaşık $126.696 \mathrm{~m}$ dere bulunmaktadır.

íSKi 2016 yılı verilerine göre Anadolu Yakası'nda ormanlık ve kırsal alandan geçen ve ıslahına gerek olmayan dere metrajı 193.712 m.dir (yaklaşık \%15). ISKİ, 2016-2020 yılları arasında beş yıllık yatırım hedeflerinde dere ıslahlarına da yer vermektedir. ISKi 2016 yılı verilerine göre Anadolu Yakasında tüm havzalarda toplam yaklaşık $1.275 .000 \mathrm{~m}$ dereden ıslah edilmemiş ve ıslahı gereken yaklaşık $128.278 \mathrm{~m}$. dere bulunmaktadır. Buna göre, Anadolu Yakası'ndaki tüm derelerin yaklaşık \%10'luk bir kısmının ıslahı gerekmekte, ancak ıslahın yapılabilmesi ve mevcut kesitin genişletilebilmesi için uygulamada yaşanması muhtemel kamulaştırma, bina işgalleri gibi sorunların ortadan kaldırılması gerekmektedir.

\section{Bulgular Ve Değerlendirme}

\subsection{Bulgular}

Afet zararlarının azaltılması doğrultusunda, İstanbul'da dere ıslah çalışmaları yoğun bir şekilde devam etmekte olup sel ve su baskınlarına karşı yapılan çalışmalar, mevcut üst yapı ve altyapıdan doğrudan etkilenmektedir. İSKİ Genel Müdürlüğü tarafından su baskınlarına 
karşı yapılan çalışmalarda mevcut hatların işletmesinin sürdürülebilir halde tutulması öncelik arz etmektedir. Çalışmalar, kentte yaşayan nüfusun mevcut yaşam koşullarını en az etkileyecek şekilde tamamlanmaya çalışılmaktadır. Bu çalışmalar esnasında sadece inşaat faaliyetlerinden kaynaklanan sorunlar değil, mülkiyet, imar, yapılaşma vb. diğer sorunlar derelerin ıslah edilmesini geciktirmekte ve özellikle sel gibi afet olaylarının oluşma riskini artırmaktadır. Mevcut altyapı koşulları, imar planlarındaki yetersizlikler, kamulaştırma gereken yerlerde imalatların gecikmesi, diğer kurum ve kuruluşlar ile koordinasyon eksiklikleri, yetki karmaşası vb. sorunlar kent içi çalışmaları zorlaştırırken etkin müdahalede gecikmelere neden olmakta ve dolayısıyla kent yaşamını olumsuz bir şekilde etkilemektedir. Bu nedenle, dere ıslah çalışmaları sadece sel riskini ortadan kaldırmaya yönelik faaliyetler olmayıp ulaşım, gürültü ve çevre kirliliği vb. yaşam koşullarını doğrudan etkilemektedir. Bu sebeple, inşaat süreçlerinin kentlinin yaşam kalitesini negatif etkileyecek şekilde mobilize edilmemesi gerekmektedir.ISKI 2016 Yılı Faaliyet Raporu'na göre Anadolu Yakası'nda ıslahına devam edilen (2017 yılı başı itibariyle) yaklaşık 45.759 m dere bulunmakta olup tüm havzaların yaklaşık \%3'ünü oluşturmaktadır. Anadolu Yakası'nda Beykoz, Paşaköy, Tuzla, Kadıköy ve Üsküdar havzalarında dere ıslah çalışmaları devam etmektedir (ISKİ, 2016a).

2016 yılı Performans Sonuçları Tablosu'nun “Dere Islah İnşaatının Yapılması” başlıklı faaliyette 2016 yılı içerisinde ıslahı tamamlanması planlanan dere metrajı $31.1 \mathrm{~km}$ iken kamulaştırma, ruhsat problemleri ve yaz aylarında çalışmaya mani durumların ortaya çıkması sebebiyle hedeflenen değere ulaşılamadığı, sadece $12.02 \mathrm{~km}$ oranında imalat gerçekleştirildiği, ulaşılması gereken hedefin sadece \%39'u gerçekleştirildiği görülmektedir (ISKI, 2016b). 2018 yılı Performans Sonuçları Tablosu'nun “Inşaatı Tamamlanan Dere Islah Uzunluğu" başlıklı faaliyette 2017 yılında tahmini 23,15 km dere ıslahı yapıldığı, 2018 yılı içerisinde ise $16,44 \mathrm{~km}$ dere ıslahı yapılması hedeflendiği belirtilmektedir (ISKI, 2018). Diğer yandan, İSKi 2016-2020 Stratejik Planı'nda 2017 yılında 19.95 km, 2018 yılında 13.31 km, 2019 yılında $19.89 \mathrm{~km}, 2020$ yılında ise $24 \mathrm{~km}$ dere ıslahı yapılması planlanmıştır. Ancak kamulaştırma problemleri, kazı ruhsatı alınamaması, kadastral problemler, güzergâhtaki mevcut binaların yıkımıyla ilgili sürecin ve planlanan dere kesiti içinde kalan mevcut altyapıların deplase işlemlerinin zaman alması sebeplerinden ötürü önümüzdeki yıllarda hedeflenen ıslah inşaatlarına da ulaşılamayabileceği belirtilmektedir (ISKİ, 2015).

İstanbul'da yapılan tüm altyapı inşaat çalışmaları, İ.B.B. Yol Bakım ve Altyapı Koordinasyon Daire Başkanlığına bağlı Altyapı Koordinasyon Müdürlüğü'nün izin ve kazı ruhsatına tabidir (Url-2). Özellikle yağış mevsimlerinde trafiğin aksamaması ve kamyonlardan kaynaklanan sebeplerden yolların kirlenmemesi açısından kazı izni verilmemektedir. Altyapı Koordinasyon Müdürlüğü'nün kazı izni vermediği durumlarda imalatı gerçekleştirecek kurumun yatırımları aksayabilmekte, daha sonraki yıllara sarkabilmektedir. ISKi Genel Müdürlüğü'de altyapı kazı çalışmalarında aynı süreçlerle muhatap olmakta, izin süreçlerinden kaynaklanan sebeplerden yatırımların gerçekleştirilmesi gecikebilmektedir. ISKK Atıksu İnşaat Daire Başkanlığı 2016 yılı performans programında da ruhsat alınamadığından dere ıslah inşaatlarında istenilen performansa ulaşılamadığından bahsedilmektedir (ISSKI, 2017).

İstanbul, dere yataklarında özel mülkiyete konu birçok parsel bulunan bir metropol olarak kendine düşen payı almış görünmektedir. Özellikle Marmara Denizi'ne dökülen derelerin D100 ve Marmara Denizi arasındaki kısımları kamulaştırma gerektirdiğinden dolayı ıslah edilememektedir. Islah edilemeyen derelerin bu kısımlarında ileriki yağış dönemlerinde sel olma riski oldukça fazladır. Şekil 3'te açıkça görüldüğü gibi, bazı dere güzergâhlarının büyük bir kısmı şahıs parsellerinden geçmekte, bu güzergâhlarda kamulaştırma gerektiğinden imalata hemen başlanılamamakta, dolayısıyla ıslah gecikmektedir. 
Sel ve İstanbul: Sel Riskine Karşı Yapılan Dere Islah Çalışmaları ile İlgili Bir Değerlendirme

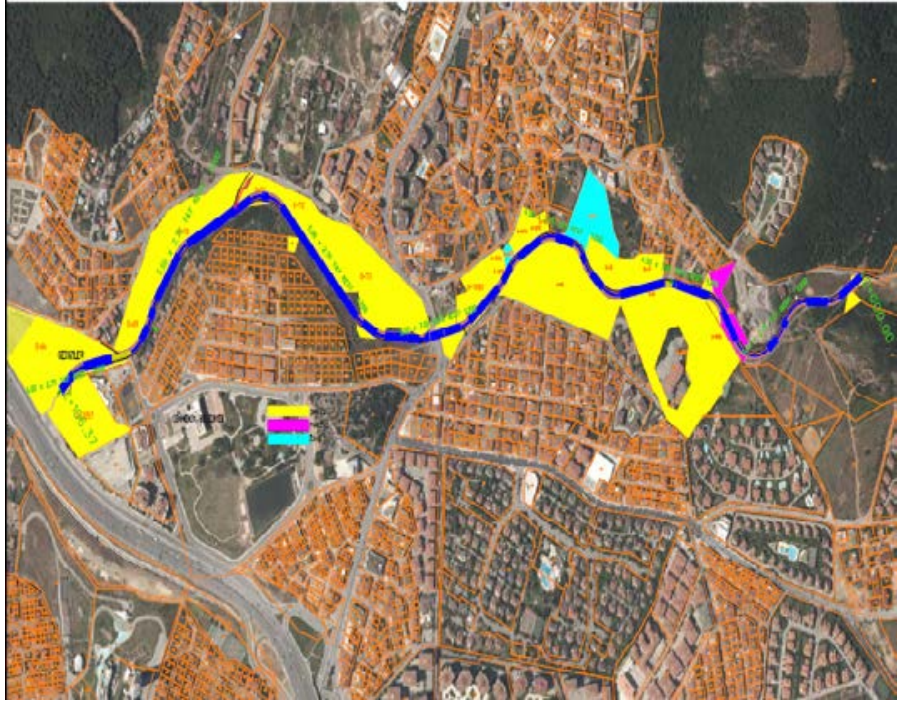

Şekil 3. Çekmeköy Deresi mülkiyet durumu, Çekmeköy.
Özel

Maliye İski

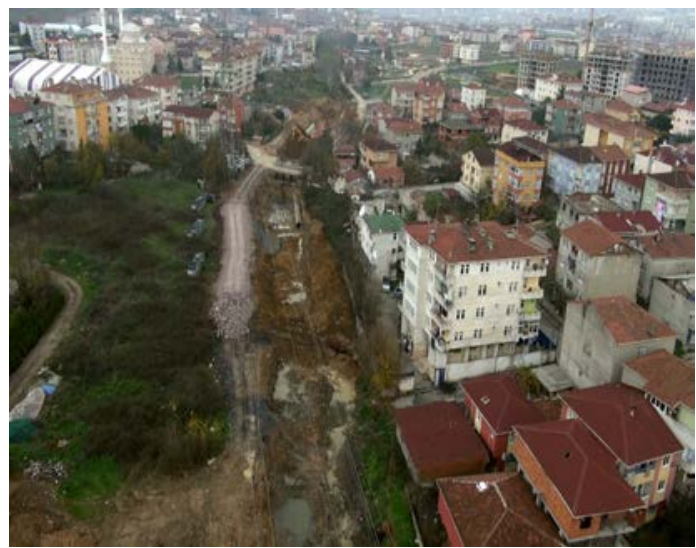

Şekil 4. Ayazma deresi ıslah çalışmaları, Sancaktepe.

Şekil 4'te görüldüğü gibi dere ıslah aşamasında dere güzergâhında bulunan birçok bina bulunmakta ve bu yapılar imalatı engellemektedir. Ayrıca, imalatın devamı için mevcut bazı yapıların korunması amacıyla zemin iyileştirilmesi gibi birtakım çözümler getirilmekte, ancak bu çözümlerle birlikte imalat maliyeti artırmaktadır. Dere ıslah çalışmalarında karşılaşılan diğer bir durum ise dere güzergâhlarında bulunan anıt niteliğindeki tarihi yapılardır. Sıklıkla karşılaşılmasa da, özellikle şehrin tarihi alanlarında oldukça fazla anıtsal yapıya rastlanıldığından dere ıslahında gecikmeler yaşanmaktadır.
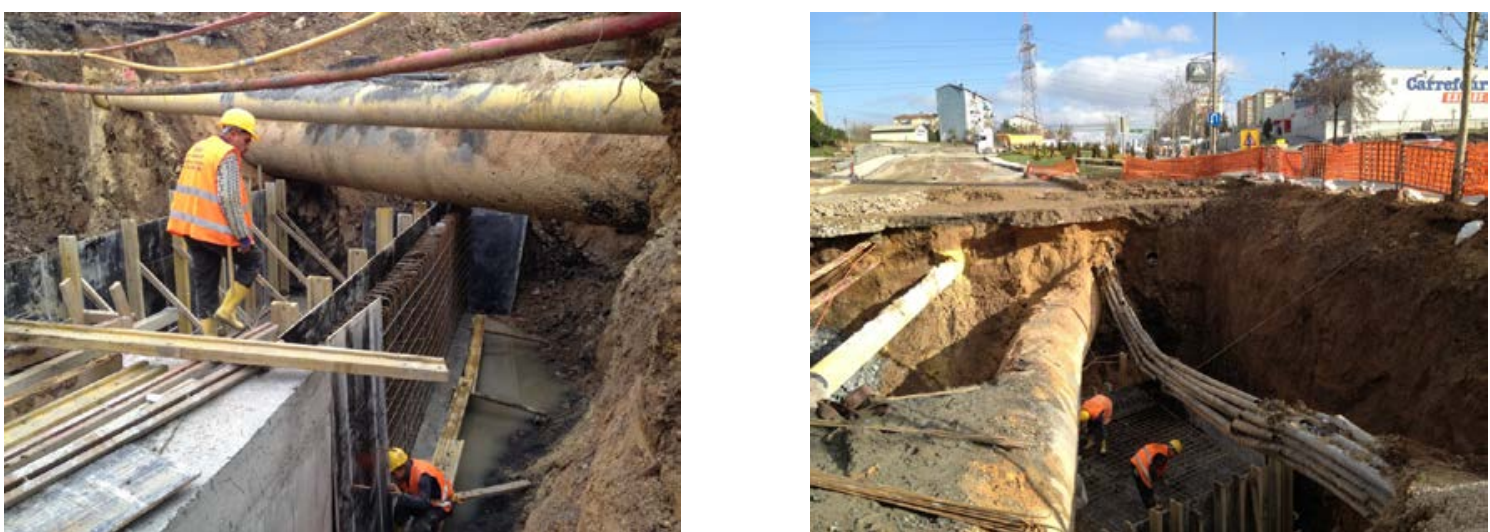

Şekil 5. Ördekçi deresi ıslah çalışmaları, Ümraniye. 
Şekil 5'te Sultanbeyli ilçesi sınırlarında bulunan Uzundere dere ıslah çalışmaları gösterilmektedir. Şekilde görüldüğü gibi, ıslah çalışmaları yaparken, dere güzergâhında telekomünikasyon, doğalgaz ve elektrik hatları gibi diğer kurum ve kuruluşlara ait mevcut altyapı hatları ile sıklıkla karşılaşılmaktadır. Islah güzergâhına denk gelen hatlar deplase edilmekte veya korunacak ve zarar görmeyecek şekilde yerinde kalabilmektedir. Ancak, deplase edilmesi gereken hatların kurumların mevcut yatırım programları, bütçelerinin uygun olup olmaması gibi nedenlerle deplaselerinde gecikmeler yaşanmaktadır. Deplase edilmemiş hatlar, herhangi bir yağış durumunda korumasız bulunduğundan bölgeye verilen hizmette aksamalar yaşanabilmektedir.

Yukarıda belirtildiği şekilde, yapılan çalışmaların mevcut yaşam koşullarını olumsuz etkilememesi, iş sağlığı ve güvenliği kurallarına uygun bir şekilde gerçekleştirilmesi konusunda ilgili kurumun istediği seviyede olmadığı ve çalışmaların yetersiz olduğu gözlenmiştir. Bunun sebeplerinden birisinin mevcut yaşam alanlarıyla dere yataklarının çarpık kentleşme sonucunda birarada olması iken, diğer eksiklikliklerden biri ve önemlisi ise sahada çalışma yapan ilgili firma yetkililerinin çalışmayı yeterince önemseyerek benimsememesi ve firma saha çalışanlarının (iş̧̧i, usta vs.) eğitim seviyesinin düşüklüğünün istenilen düzeyde ve kalitede hizmet alınmasını engellemesi olarak ortaya çıktığı düşünülmektedir.

\subsection{Değerlendirme}

Türkiye'nin değişen sosyal ve ekonomik yapısı karşısında sel ve taşkınların önemi artmaktadır (Özmen, 2015). Türkiye'de meteoroloji karakterli veya hidrometeorolojik olaylar sık sık birer afete dönüşerek gelişmiş ülkelere nazaran çok daha fazla insan ve ekonomik kayıplara neden olması ile birlikte, geçerli çözümler de geliştirilememektedir (Kadıoğlu, 2008). Türkiye sel ve taşkın riskini her zaman için taşımaktadır. Artan nüfus ve buna paralel olarak şehirleşme alanının genişlemesi, bu esnada yapılan planlama hataları, tahrip edilen doğa ve değişen iklim koşulları ile birlikte bu risk ve zararın boyutu gittikçe artmaktadır (Sepetçioğlu, 2013).

İstanbul'un kentsel gelişimi içerisinde derelerin fiziki yapısı doğrudan etkilenmiştir (Dinç ve Bölen, 2014). İstanbul Anadolu Yakası'nda bulunan dereler incelendiğinde ıslah edilmesi gereken dere güzergâhlarının yoğun işgal ve özel mülkiyet içerisinde kaldığı gözlenmektedir. $\mathrm{Bu}$, dere güzergâhlarının yeterince korunmadığı anlamına gelmekte ve kamulaştırma maliyetlerinin her geçen gün arttığı göz önünde bulundurulduğunda dere ıslah tekniklerinin alternatif yöntemlerle yapılmasını gerekli kılmaktadır. Özellikle çoğunluğun yaşadığı D-100 ile deniz arasında kalan bölgenin kamulaştırmasının zorluğu ele alındığında bu alandaki Marmara Denizi'ne mansaplı derelerin D-100 üzerinden Ömerli Barajı'na aktarılabilmesi için kamulaştırma masraflarının en aza indirgenmesi gibi sel riskini azaltıcı bir takım proje ve araştırmalara intiyaç bulunmaktadır. Bu tip araştırmaların ilgili kurum, kuruluş ve üniversite gibi uzman gruplarla yapılması çözüm geliştirmede önem arz etmektedir.

Afetlerle ilgili çok sayıda birimin bulunmasına karşılık bu birimler arasındaki koordinasyon eksikliği, yetki karmaşası, kurumların birbirinden habersiz hareket etmesi, kanuni eksiklikler afet sonrası manzaraların hep aynı kalmasına yol açmaktadır (Kara, 2007). İstanbul'da birçok kurum altyapı çalışmaları yapmakta olup hali hazırda altyapı tesislerine sahiptir. Dere ıslahı inşaatları açısından değerlendirildiğinde kurumlar arasındaki koordinasyon eksikliği göze çarpmaktadır. Dere güzergâhlarının işgal altında olması dolayısıyla altyapı hatlarının dere güzergâhından geçmesi çarpık kentleşmelerin olduğu şehirlerde doğal ve kaçınılmaz bir olgudur. Dere ıslah imalatlarında inşaat aşamasında mevcut hatların zamanında deplase edilememesi ve korunaklı hale getirilememesi kurumlar arasındaki koordinasyonsuzluğun tipik bir örneğidir. 
Araştırmada, sel riskini azaltmaya yönelik faaliyetlerin çok daha etkin bir şekilde tamamlanabilmesi için birtakım hukuki ve kurumsal düzenlemelere ihtiyaç olduğu bir kez daha vurgulanmaya çalışılmıştır.

\section{Sonuç}

Bir kamu kuruluşu olarak ISKI Genel Müdürlüğü su baskınlarına karşı yaptığı dere ıslahlarında oldukça başarılı işler yapmaktadır. Ancak imalat aşamasında ortaya çıkan problemler, standart uygulamalar, diğer kurum ve kuruluşlar ile koordinasyon v.b. ortaya çıkan olumsuzluklar çalışmalarda eksikliklere ve gecikmelere neden olmaktadır. Bunun giderilebilmesi için, diğer kurum ve kuruluşları da içine alacak hukuki birtakım düzenlemeler, yetki karmaşasının önüne geçilmesi bakımından kurumun kendi içerisinde sel baskınlarına yönelik yeni bir organizasyona gitmesi, acil intiyaç durumlarında koordinasyon eksikliklerinin giderilmesi açısından ise standart birtakım uygulama prosedürlerinin uygulamaya geçirilmesi gerekmektedir.

Şehir içinde yapılan altyapı ve üstyapı çalışmalarında en önemli şeylerden birisi normal yaşam koşullarının çalışmalardan etkilenmeden rutininde devam etmesini sağlamaktır. İstanbul gibi büyük bir metropolde, her yanında çarpık kentleşme, ulaşım, çevre vb. diğer sorunlar sebebiyle mevcut yaşam koşullarına dokunmadan üst/altyapı projelerinin hayata geçirilmesi oldukça zor görünmektedir. Ancak riski minimum indirebilmek için yapılacak olan birçok çalışma bulunmaktadır. Yukarıda da belirtildiği gibi, dere ıslah çalışmaları sadece bir inşa faaliyeti değildir. Bu faaliyeti gerçekleştiren kurum personelinin, daha da önemlisi sahada çalışan işçilerin, ustaların ve firma yetkililerinin bu konuya gereken önemi vermeleri için çalışma alanı ve şartları ile ilgili önceden gerekli eğitim, bilgilendirme, uyarma gibi faaliyetlerin çalışmalar başlamadan zorunlu kılınması ve çalışanlara sunulması gerekmektedir. Böylece, dere ıslah çalışmalarının yeterliliği ve kalitesi artacaktır.

Sonuç olarak; sel ve taşkın olaylarından daha etkili bir şekilde korunmak için her bir yerleşim ve dere güzergâhı için uygun ıslah metodunun belirlenmesi, riskin azaltılmasına yönelik çalışmaların artırılması ve karar vericilerin bunun bir politika haline getirilmesi için çalışmalarına aralıksız devam etmesi gerekmektedir. 


\section{KAYNAKLAR}

Bahçeci, F. (2014). Kırsal ve Kentsel Yerleşim Alanlarındaki Dere Yataklarının Islahında Öne Çıkan İdari, Teknik ve Çevresel Sorunlar. Yüksek Lisans Tezi, İstanbul Teknik Üniversitesi, Fen Bilimleri Enstitüsü, İstanbul.

Bingöl, Y. (2006). İstanbul Derelerinin Mevcut Durumu ve Taşkın Debilerinin Hesabı. Yüksek Lisans Tezi, İstanbul Teknik Üniversitesi, Fen Bilimleri Enstitüsü, İstanbul.

Ceylan, A., Ayvacı, H., Akgündüz, S., Hüküm, H., Güser, Y. (2015). Şehir Selleri Tahmin ve Erken Uyarı Modeli. https://www.mgm.gov.tr/FILES/genel/makale/sehirselleri_atmos.pdf [Erişim 11 Ocak 2018].

Dinç, H., Bölen, F. (2014). İstanbul Derelerinin Fiziki Yapısı. Planlama, 24 (2), 107120. http://www.journalagent.com/planlama/pdfs/PLAN-97269-OPINION_LETTER-DINC.pdf

Dölek, İ. (2015). Sungu Beldesi ve Yakın Çevresinde (Muş) Sel ve Taşkına Duyarlı Alanların Belirlenmesi. Marmara Coğrafya Dergisi, 0 (31), 258-280. DOI: 10.14781/mcd.26466.

Ergünay, O., (2007), Türkiye'nin afet profili.

http://www.imo.org.tr/resimler/ekutuphane/pdf/3885.pdf [Erişim 11 Ocak 2018].

Garipağaoğlu, N. (2016). Marmara Havzası'nda Kentleşme - Atık Su İlişkileri ve Alıcı Ortam Üzerindeki Etkileri. Marmara Coğrafya Dergisi, 34, 147-159.

Gönüllü, A . (2010). Osmanlı Devletinin Son Döneminde Meydana Gelen Sel Baskınları (1857-1913). Selçuk Üniversitesi Türkiyat Araştırmaları Dergisi, (28), 351-373. http://dergipark.gov.tr/sutad/issue/26258/276616

ISKI Genel Müdürlüğü. (2013a). Dere Islah Çalışmaları [Power Point Sunumu].

ISKI Genel Müdürlüğü. (2013b). Performans Sonuçları Tablosu. ISKi Genel Müdürlüğü, İstanbul.

ISKI Genel Müdürlüğü. (2015). Stratejik Plan 2016-2020. ISKKI Genel Müdürlüğü, İstanbul.

ISKi Genel Müdürlüğü. (2016a). Faaliyet Raporu. İSKI Genel Müdürlüğü, İstanbul.

ISKI Genel Müdürlüğü. (2016b). Performans Sonuçları Tablosu. ISKI Genel Müdürlüğü, İstanbul.

ISKI Genel Müdürlüğü. (2017). Performans Sonuçları Tablosu. İSKi Genel Müdürlüğü, İstanbul.

ISKİ Genel Müdürlüğü. (2018). Performans Sonuçları Tablosu. İSKI Genel Müdürlüğü, İstanbul.

Kadıoğlu, M., (2008). Sel, Heyelan ve Çığ için Risk Yönetimi; Kadıoğlu, M. ve Özdamar, E., (editörler), "Afet Zararlarını Azaltmanın Temel İlkeleri”; s. 251-276, JICA Türkiye Ofisi Yayınları No: 2, Ankara.

Kadıoğlu, M. (2012) Türkiye'de İklim Değişikliği Risk Yönetimi. Türkiye'nin İklim Değişikliği II. Ulusal Bildiriminin Hazırlanması Projesi Yayını. 
Kara, H. (2007). Türkiye'deki Şehir Yerleşmelerinde Afet Sonrasına Yönelik "Afet Merkezleri" Plânlaması, TMMOB Afet Sempozyumu, 5-7 Kasım 2007, s. 279-288. http://www.imo.org.tr/resimler/ekutuphane/pdf/3908.pdf [Erişim 11 Ocak 2018].

Karakuyu, M. (2002). Şehirleşmenin Küresel İklim Sapmaları ve Taşkınlar Üzerindeki Etkisi. Marmara Coğrafya Dergisi, 6, 97-108.

Korkanç, S. Y. (2005). Sel ve Taşkınlardan Korunmada Erken Uyarı ve Önemi. FORESTIST (eski adıyla İstanbul Üniversitesi Orman Fakültesi Dergisi), 55 (1), 123-134. http://dergipark.gov.tr/jffiu/issue/18711/197342

Kömüşçü, A. Ü., Çelik, S., Ceylan, A. (2011). 8-12 Eylül 2009 Tarihlerinde Marmara Bölgesi'nde Meydana Gelen Sel Olayının Yağış Analizi, Coğrafi Bilimler Dergisi, 9 (2), 209220.

Özcan, E. (2006). Floods and Turkey. Gazi Üniversitesi Gazi Eğitim Fakültesi Dergisi, 26 (1), 35-50. http://dergipark.gov.tr/gefad/issue/6754/90823

Özmen, M.T. (2015), Sel-taşkın Türkiye ve Antalya. http://www.imo.org.tr/resimler/dosya_ekler/97e314f2b9acbd2_ek.pdf [Erişim 11 Ocak 2018].

Sepetçioğlu, M.Y. (2013). Şanlıurfa İli Taşkın Sorunları ve Çözüm Önerileri. NWSAEngineering Sciences, 1A0339, 8 (1), 21-38.

Sönmez, M.E., Kesici, Ö. (2012). İklim Değişikliği ve Plansız Şehirleşmenin Kilis Şehrinde Yol Açtığı Sel Felaketleri. Doğu Coğrafya Dergisi, 28, 57-78.

Şahin, C., Sipahioğlu, S. (2002). Doğal Afetler ve Türkiye, Gündüz Eğitim Yayıncılık, Ankara.

T.C. Anayasası. (1982). T. C. Resmi Gazete, 17863, 09 Kasım 1982.

T.C. Büyükşehir Belediyesi Kanunu. (2004). T. C. Resmi Gazete, 25531, 23 Temmuz 2004.

T.C. Orman ve Su İşleri Bakanlığı. (2017). Taşkın Yönetimi Çalışma Grubu Raporu. 2. Ormancılık ve Su Şurası, 4-6 Mayıs, Ankara.

Turgu, E., Ceylan, A. (2008). ECMWF Yağış Verileri Yardımıyla Türkiye'de Sel Tahmini Çalışmaları, Uluslararası Katılımlı VI. Atmosfer Bilimleri Sempozyumu, 25-28 Mart 2008. https://www.mgm.gov.tr/FILES/genel/makale/seltahmini.pdf [Erişim 11 Ocak 2018].

(Url-1). https://www.mgm.gov.tr/arastirma/dogal-afetler.aspx?s=taskinlar [Erişim 11 Ocak 2018].

(Url-2). https://www.ibb.istanbul/CorporateUnit/Detail/85 [Erişim 11 Ocak 2018].

(Url-3). https://www.afad.gov.tr/tr/2211/AFAD-Hakkinda. [Erişim 11 Ocak 2018].

Zeybek, İ . (1998). 22 Mayıs 1998 Havza Sel-Taşkın Felaketi. Ondokuz Mayıs Üniversitesi $\begin{array}{lllll}\text { Eğitim } \quad \text { Fakültesi } & \text { Dergisi, } & 11 & \text { 160-167. }\end{array}$ http://dergipark.gov.tr/omuefd/issue/20259/215171. 